\title{
DO PROCESSO ELETRÔNICO AO DOCUMENTO PÚBLICO: UMA ANÁLISE DA CONSERVAÇÃO DOS AUTOS COMO ARQUIVOS PERMANENTES
}

\author{
FROM ELECTRONIC PROCESS OF LAW TO PUBLIC DOCUMENT: AN \\ ANALYSIS OF CONSERVATION OF COURT CASE AS A PERMANENT FILES
}

\section{DEL PROCESO ELETRÓNICO AL DOCUMENTO PÚBLICO: UN ANÁLISIS DE LA CONSERVACIÓN DE LOS AUTOS COMO ARCHIVOS PERMANENTES}

\begin{abstract}
ELAINE HARZHEIM MACEDO
Doutora em Direito pela Universidade do Vale do Rio dos Sinos. Professora catedrática adjunta, permanente, da Pontifícia Universidade Católica do Rio Grande do Sul, professora palestrante da Escola Superior de Magistratura Ajuris. (Porto Alegre, Rio Grande do Sul, Brasil) http://lattes.cnpq.br/0208696518341737 / http://orcid.org/0000-0003-0379-4873 / elaine@fhm.adv.br
\end{abstract}

RENAN MATHEUs MACEDO TOLFO Advogado. Graduado em Direito pela Pontifícia Universidade Católica do Rio Grande do Sul. Membro do Grupo de Pesquisa "Jurisdição, Efetividade e Instrumentalidade do Processo", vinculado ao CNPq. Pontifícia Universidade Católica do Rio Grande do Sul. (Porto Alegre, Rio Grande do Sul, Brasil) http://lattes.cnpq.br/3755986526338848 / http://orcid.org/0000-0002-9957-6485 / renanmattheus@gmail.com

\begin{abstract}
RESUMO
A gestão dos documentos produzidos pelo Poder Judiciário no exercício de sua função jurisdicional constitui dever constitucional da administração pública judiciária, tendo a guarda e o acesso a esses documentos importante ponto de conexão entre a História, a Arquivologia e o Direito. Como problema, tem-se o risco da preservação inadequada de arquivos eletrônicos judiciais. Neste estudo, tem-se como objetivo encontrar um sistema que cumpra os requisitos arquivísticos de preservação. Utiliza-se do método dedutivo, tendo como premissa maior o dever de preservação dos documentos. A premissa menor advém da guarda dos arquivos eletrônicos que representam o processo judicial. 0 método auxiliar tipológico foi escolhido em busca de um tipo ideal de sistemática de preservação. Utiliza-se de pesquisa bibliográfica e documental da legislação pátria, explicando o fenômeno e propondo possível solução à manutenção de tais documentos, concluindo-se pela utilização do Archivematica no Poder Judiciário.
\end{abstract}

Palavras-chave: Arquivos judiciais; Conservação dos autos; Documentos digitais; E-processo.

\section{ABSTRACT}

The management of documents produced by the Judiciary in the exercise of its judicial function constitutes a constitutional duty of the judicial public administration, since custody and access to these documents are important points of connection between History, Archives and Law. As a problem there is the risk of inadequate preservation of electronic judicial files. The purpose of this study is to find a system that meets the archival preservation requirements. The deductive method is used, having as main premise the duty of preservation of documents. A minor premise derives from the custody of the electronic files representing the judicial process. The typological auxiliary method was chosen in search of an ideal type of systematic preservation. It uses bibliographic and documentary research of the national legislation, explaining the phenomenon and proposing a possible solution for document maintenance, concluding by the use of Archivematica in the judiciary.

Keywords: Judicial files; Preservation of court cases; Digital documents; Virtual process. 


\section{RESUMEN}

La gestión de los documentos producidos por el Poder Judiciario en el ejercicio de su función jurisdiccional constituye deber constitucional de la administración pública judiciaria, siendo la guardia y el acceso a esos documentos importante punto de conexión entre la Historia, la Archivología y el Derecho. El riesgo de la preservación inadecuada de los archivos electrónicos judiciales es un problema. En el presente estudio, tenemos el objetivo de encontrar un sistema que cumpla con los requisitos archivísticos de preservación. Utilizamos el método deductivo, siendo la premisa mayor el deber de preservación delos documentos. La premisa menor adviene de la guardia de los archivos electrónicos que representan el proceso judicial. El método auxiliar tipológico se ha elegido en busca de un tipo ideal de sistemática de preservación. Utilizándonos de la investigación bibliográfica y documental de la legislación patria, explicaremos el fenómeno y propondremos una solución posible a la manutención de tales documentos, concluyéndonos por la utilización del Archivematica en el Poder Judiciario.

Palabras clave: Archivos judiciales; Conservación de los autos; Documentos digitales; E-proceso.

\section{SUMÁRIO}

INTRODUÇÃO; 1 O ARQUIVO NO PODER JUDICIÁRIO; 2 A PRESERVAÇÃO DOCUMENTAL COMO DEVER DO ESTADO; 3 A SISTEMÁTICA DA PRESERVAÇÃO DO ARQUIVO DIGITAL; 3.1 Os requisitos fundamentais da preservação de longo prazo; 3.2 Da seleção de documentos; 3.3 Do Archivematica como Repositório Arquivístico Digital Confiável; CONCLUSÃO; REFERÊNCIAS.

\section{INTRODUÇÃO}

História e Direito, como fenômenos culturais, andam juntos. O fenômeno do processo judicial, responsável pela própria existência do Poder Judiciário e da função de pacificação social traduzida pela composição dos conflitos, gerou na contemporaneidade a institucionalização do Poder Judiciário, de regra como um dos poderes do Estado. E o processo, como canal da jurisdição, se reproduz em autos, ou seja, na documentação de seu procedimento, isto é, atos que se sucedem no tempo, irrelevante, para efeito de memória, qual a tecnologia utilizada para o registro documental. Processo como espaço do exercício da jurisdição, autos do processo como documentação dos atos e práticas processuais. Desde a invenção do papiro até o presente, é ainda o papel importante ferramenta para o registro de atos da vida privada ou pública, mas nas últimas décadas a humanidade conheceu e desenvolveu forma alternativa de registro: a documentação digital. O Judiciário não está imune a essas evoluções, e o e-processo passou a ser contemplado, no direito pátrio, como opção útil e necessária ao seu desiderato. Marco temporal para o e-processo é a Lei $n^{\circ} 11.419$, de 2006, ainda que, cediço, o caminho para a completa e geral informatização do processo é longo, custoso e penoso, por razões que fogem ao objetivo deste trabalho.

Por outro lado, é norma constitucional o dever do Poder Público, com a colaboração da comunidade, promover e proteger o patrimônio cultural brasileiro, incluindo sua preservação, e 
ISSN 1981-3694

(DOI): 10.5902/1981369425362

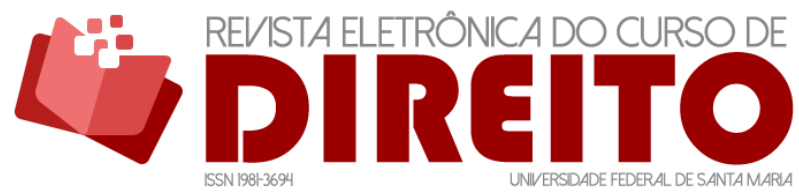

DO PROCESSO ELETRÔNICO AO DOCUMENTO PÚBLICO: UMA ANÁLISE DA CONSERVAÇÃO DOS AUTOS COMO ARQUIVOS

PERMANENTES

ELAINE HARZHEIM MACEDO RENAN MATHEUS MACEDO TOLFO

é dever da administração pública a gestão da documentação governamental, franqueando a sua consulta a quantos dela necessitam. A guarda só tem sentido se o documento guardado for de livre acesso. Aqui se constata um importante ponto de conexão entre os ditames da História e a produção da atividade jurisdicional, função que integra a soberania nacional e que a Constituição atribui ao Poder Judiciário.

Por certo que a guarda dos documentos produzidos no exercício da função jurisdicional assume vital importância e inúmeras dificuldades a serem vencidas, seja da classificação documental às práticas e métodos a serem utilizados na preservação, do papel ao meio digital, que em futuro próximo deverá ser a única forma de documentação dos autos do processo. Isso deve ser feito cumprindo as melhores práticas da Arquivologia, de modo a garantir que a preservação seja de fato permanente. A guarda inadequada pode trazer sérios riscos ao arquivo digital, comprometendo, dentre outros, sua integridade, valor probatório e até histórico. Tal problema constitui-se num risco que deve ser minimizado através da inserção de um sistema de gestão que consiga atender aos requisitos arquivísticos de preservação.

Com o objetivo de encontrar um repositório confiável, este estudo utiliza do método dedutivo, tendo como premissa maior o dever de preservação dos documentos. A premissa menor extrai-se da necessidade de preservação dos arquivos eletrônicos que representam o processo judicial. De forma auxiliar, o método tipológico foi escolhido de forma a representar um tipo ideal de sistemática de preservação. Assim, far-se-á uma análise de como cumprir a premissa do dever de preservação de arquivos eletrônicos permanentes do Poder Judiciário. Como técnica de pesquisa, foi utilizada a bibliográfica e documental da legislação pátria, propondo ser explicativa acerca da necessidade da guarda e do acesso aos documentos preservados.

Verifica-se ainda que é necessária a utilização geral de um Repositório Arquivístico Digital Confiável pelo Poder Judiciário, de modo que se possa preservar e dar acesso a documentos permanentes de maneira correto. Desse modo, o estudo busca, partindo de um panorama de ambientação histórica, passar pela normatividade que rege a preservação documental, física e digital, chegando na sistemática atual de gestão de documentos no Poder Judiciário. Por fim, explica o porquê da utilização de um repositório digital para os fins presentes neste artigo. Como caráter propositivo, apresenta possível indicação à manutenção de tais documentos por meio da utilização do Archivematica, que vem se tornando reconhecido por assegurar o cumprimento dos conceitos e requisitos arquivísticos de preservação digital. 


\section{ARQUIVO NO PODER JUDICIÁRIO}

Tratando-se de preservação documental pelo Poder Público, arriscamos a dizer que estamos em alinhamento - ou pelo menos a caminho dele. Um dos indicativos é o de que, como ainda será melhor abordado, diversas leis e atos normativos estão espalhados pelo arcabouço jurídico, na tentativa de se tornarem referência na gestão e tratamento de documentos públicos.

Os Tribunais de todo país passam por uma tarefa árdua na administração de seus documentos pela dificílima demanda que representam no desiderato de sua preservação, quando já encontrados em seu terceiro ciclo vital. Na atualidade é crescente a existência de arquivos judiciais lotados por autos de processos produzidos em papel, ao longo do tempo, que deveriam servir de fonte de pesquisa ou efetivação do acesso à informação. É bem verdade que estão sofrendo os efeitos de sua guarda, na maioria das vezes precária, e mostrando-se por muito inutilizáveis, a ponto que se questiona: que acesso à informação se dá com folhas que mal podem ser tocadas, sob pena de se desconstituírem?

Desde 1980 ocorre o chamado processo de informatização das instituições do Poder Judiciário. O caminho foi longo e tumultuado, longe de estar vencido, por inúmeras razões, inclusive o fator econômico e a própria questão cultural, produzindo um sentimento de insegurança em relação ao sistema informatizado. No ponto, Carlos Henrique Abrão saúda a agilidade e rapidez propiciadas pelo desenvolvimento tecnológico ${ }^{1}$, também indicando que tais mudanças foram aceleradas a partir da Lei $n^{\circ} 11.419$, de 2006 , eis que dela constou a previsão de diversas disposições acerca da informatização do processo judicial. Voltando no tempo um pouco mais, no que se refere ao Código de Processo Civil anterior, Lei $n^{\circ} 5.869$, de 11 de janeiro de 1973, houve também a realização de adaptações necessárias, ainda que franciscanas. Hoje, na leitura do Manual de Gestão Documental e no Manual de Requisitos apresentados pelo Conselho Nacional de Justiça ${ }^{2}$, albergam-se disposições importantes sobre a correta preservação, ainda que diga respeito às características de ambos os materiais, pois o material físico, que se

\footnotetext{
1 “Não há mais espaço, em muitos Estados da Federação, para arquivos, gastos e demoras no desarquivamento. Agora com armazenamento em memória eletrônica, o documento em papel fica no estágio acessório, e ganha espaço a rede com toda a potência e submetida, cada vez mais, às transformações da tecnologia moderna". Cf. ABRÃO, Carlos Henrique. Processo eletrônico: Lei n 11.419 de 19 de dezembro de 2006. 2. ed. São Paulo: Revista dos Tribunais, 2009. p. 14.

2 BRASIL. Conselho Nacional de Justiça. Modelo de Requisitos para Sistemas Informatizados de Gestão de Processos e Documentos do Judiciário brasileiro - MoReq-Jus. Disponível em: <http://www.cnj.jus.br/images/programas/gestao-documental/rescnj_91.pdf>. Acesso em: 15 ago. 2016.
} 
torna digital, muda-se de igual modo para uma entidade lógica e conceitual, merecendo uma revisão das políticas de segurança, além da devida preservação.

A nova perspectiva de documentação digital provou de alterações na legislação que trouxeram diversas mudanças no que concerne à sua produção, transmissão, armazenamento e também ao acesso a esses documentos ${ }^{3}$. Todavia, uma progressiva preocupação toma conta de todos os ânimos que se envolvem por esse mundo: segurança. Isso porque intervenções não autorizadas, adulteração ou perda dos documentos podem ocorrer, o que levanta o questionamento sobre até que ponto é tão eficiente tal iniciativa ${ }^{4}$.

Outrossim, os documentos apresentam suportes diferenciados quando físicos ou digitais. Além de tais suportes ${ }^{5}$, há o devido registro de suas políticas, funções, decisões e procedimentos em tais documentos. Igualmente, precisam ser confiáveis, autênticos, acessíveis, compreensíveis e preserváveis ${ }^{6}$, o que não é possível alcançar sem que um programa de gestão de processos e documentos esteja efetivamente implantado ${ }^{7}$.

\footnotetext{
3 “Além disso, já estão disponíveis no mercado as tecnologias tais como multi-touch (multitoque) e a $e$-ink (tinta eletrônica) e até a visão computacional e o reconhecimento de voz, que em breve fornecerão soluções mais ergonômicas para o processo eletrônico. Já está disponível, também, inclusive, o chamado e-paper, de oleds ou leds orgânicos que permitem confeccionar monitores bem finos, na espessura de um papel e, inclusive, flexíveis. Existe inclusive uma anedota que marca bem a superação dessas preocupações com o conforto da manipulação eletrônica, pois para os que preferem ainda o velho processo de papel, já se pode vislumbrar o processo de e-papel”. Cf. CHAVES JÚNIOR, José Eduardo de Resende. 0 processo em rede. In: CHAVES JÚNIOR, José Eduardo de Resende (Coord.). Comentários à lei do processo eletrônico. São Paulo: LTr, 2010. p. 20.
}

4 BRASIL. Conselho Nacional de Justiça. Manual de gestão documental. Disponível em: <http://www.cnj.jus.br/images/programas/gestaodocumental/manual_gestao_documental_poder\%20judi ciario.pdf>. Acesso em: 15 ago. 2016.

5 "Dessas definições, é possível depreender que o suporte é eletrônico e a informação, ou seja, o conteúdo do documento, somente é acessível através do auxílio de um computador. Por isso, pode-se entendê-la também como uma informação que só existe em meio eletrônico e, mesmo assim, deve ainda conter as características dos documentos arquivísticos tradicionais. Sendo assim, independente de ser ou não um documento eletrônico, para ser um documento arquivístico o mesmo precisa respeitar os princípios e as características dos documentos arquivísticos ditos convencionais". Cf. NEGREIROS, Leandro Ribeiro; DIAS, Eduardo José Wense. A prática arquivística: os métodos da disciplina e os documentos tradicionais e contemporâneos. Perspectivas em Ciência da Informação, v. 13, n. 3, p. 2-19, set./dez. 2008. Disponível em: <http://www.scielo.br/pdf/pci/v13n3/a02v13n3.pdf>. Acesso em: 15 ago. 2016. p. 4.

6 "A prioridade para a arquivologia é a preservação dos documentos. Isto compreende, em um primeiro momento, que haja precaução contra a deterioração e danos aos documentos e, em um segundo momento - e talvez seja esse o maior desafio nesse contexto eletrônico de produção de documentos - que haja preservação das características dos documentos arquivísticos. 0 acesso aos documentos, sua identificação e sua localização, ou seja, a recuperação da informação, é importante, mas a partir do momento em que a preservação - física e intelectual - foi assegurada". Cf. NEGREIROS, Leandro Ribeiro; DIAS, Eduardo José Wense. A prática arquivística: os métodos da disciplina e os documentos tradicionais e contemporâneos. Perspectivas em Ciência da Informação, v. 13, n. 3, p. 2-19, set./dez. 2008. Disponível em: <http://www.scielo.br/pdf/pci/v13n3/a02v13n3.pdf>. Acesso em: 15 ago. 2016. p. 6.

7 BRASIL. Conselho Nacional de Justiça. Manual de gestão documental. Disponível em: 
A Teoria das Três Idades ${ }^{8}$ classifica os documentos institucionais, quanto ao seu ciclo de vida, como: correntes, intermediários e permanentes. Os instrumentos concebidos pelo Conselho Nacional de Justiça, em síntese, destinam-se à gestão dos documentos por todas as fases de seu ciclo de vida, e, como já reconhecido, com foco na eficácia administrativa, na recuperação da informação disponível, na tomada de decisões e ao cumprimento da missão institucional do Poder Judiciário.

Cumpre salientar que fatos ocorridos e que marcaram nossa sociedade estão registrados em documentos judiciais arquivísticos, museológicos e biblioteconômicos. É inexorável a necessidade de tal preservação, eis que, por meio da resolução de conflitos individuais e coletivos, o Poder Judiciário é coadjuvante - quando não protagonista - de transformações emblemáticas, como políticas, econômicas, científicas ou culturais que envolvem a sociedade? Cada processo traz em si uma história, história da vida privada, história da vida pública.

A necessidade de preservar é irrenunciável. A primeira vez que o termo apareceu na literatura foi em 1934, na obra Traité de Documentatión de Paul Otlet. Contudo, a maior visibilidade dada ao assunto somente emergiu a partir do documento da UNESCO: Memória do Mundo: diretrizes para a salvaguarda do Patrimônio Documental Mundial ${ }^{10}$.

<http://www.cnj.jus.br/images/programas/gestaodocumental/manual_gestao_documental_poder\%20judi ciario.pdf>. Acesso em: 15 ago. 2016.

8 "Fundamentada em estratégias de avaliação documental e de intervenção no ciclo vital dos documentos, a maior colaboração da teoria das três idades para que os arquivos cumpram sua função em um ambiente de produção documental crescente consiste em conduzir à determinação do trânsito do documento, até à destinação final, resultando, principalmente, na redução controlada e criteriosa da massa documental, conservada e acessível de forma eficaz, eficiente e econômica". Cf. MEDEIROS, Nilcéia Large de; AMARAL, Cléia Márcia Gomes do. A representação do ciclo vital dos documentos: uma discussão sob a ótica da gestão de documentos. Em Questão, Porto Alegre, v. 16, n. 2, p. 297-310, jul./dez. 2010. Disponível em: <http://www.seer.ufrgs.br/EmQuestao/article/view/15108/10436>. Acesso em: 14 nov. 2016. p. 298-299.

9 Vale citar a Resolução $n^{\circ} 175$, do Conselho Nacional de Justiça, que dispõe sobre a habilitação, celebração de casamento civil, ou de conversão de união estável em casamento, entre pessoas de mesmo sexo, com base na decisão do plenário do referido, tomada no julgamento do Ato Normativo $\mathrm{n}^{\circ} 0002626$ 65.2013.2.00.0000, na $169^{\text {a }}$ Sessão Ordinária, realizada em 14 de maio de 2013, considerando que o Supremo Tribunal Federal, nos acórdãos prolatados em julgamento da ADPF 132/RJ e da ADI 4277/DF, reconheceu a inconstitucionalidade de distinção de tratamento legal às uniões estáveis constituídas por pessoas de mesmo sexo, sem olvidar que o Superior Tribunal de Justiça, em julgamento do RESP 1.183.378/RS, decidiu inexistir óbices legais à celebração de casamento entre pessoas de mesmo sexo. Tais disposições corroboram a construção da memória social, na qual o Poder Judiciário agiu erigindo história em nossa época.

${ }^{10}$ A UNESCO criou o Programa Memória do Mundo em 1992. "A consciência crescente do lamentável estado de conservação do patrimônio documental e do deficiente acesso a este em diferentes partes do mundo foi o que deu o impulso original. A guerra e os distúrbios sociais, assim como severa falta de recursos, têm piorado problemas que existem faz séculos. Importantes coleções em todo o mundo vêm sofrendo diferentes destinos. 0 saque e a dispersão, o comércio ilícito, a destruição, assim como o armazenamento e o financiamento inadequados têm contribuído para esta situação. Muito do patrimônio documental desapareceu para sempre, muito está em perigo. Afortunadamente, algumas vezes redescobrem-se 
Pode-se então dizer que a história composta pela atividade jurisdicional é um verdadeiro reflexo do que ocorre no país, em vasto e amplo aspecto. Importante espaço desempenha o Conselho Nacional de Justiça, neste quesito, na medida em que incentiva e apoia as atividades de preservação e de divulgação dessa memória judiciária, que reflete a memória de nossa sociedade.

Além de ser uma necessidade do Poder Judiciário, a preservação dos documentos é uma obrigação da Administração Pública como um todo. Nasce, pois, de um dever de preservação em virtude de nossa história, de preservá-la para diversos fins. Nesse caminho, em prol do dever maior de preservação, andou a evolução legislativa nas últimas décadas, como será adiante apresentado.

\section{A PRESERVAÇÃO DOCUMENTAL COMO DEVER DO ESTADO}

Todo documento produzido ou recebido no Poder Judiciário constitui-se em patrimônio público, seja no sentido administrativo ou cultural. O Estado tem o dever de zelar por esse patrimônio, para que se possa dar concretização aos preceitos constitucionais, como o de direito ao acesso à informação ${ }^{11}$.

Nisso a Constituição Federal de 1988 , em seu art. 216 , §2², aponta que cabe à administração pública, na forma da lei, a gestão da documentação governamental e as providências para se possibilitar a consulta de tais documentos a quantos dele necessitem. ${ }^{12} \mathrm{~A}$ Lei $n^{\circ} 8.159 / 1991$ veio, na sequência, a regrar tal disposição constitucional. Também conhecida por "estatuto dos documentos públicos", a lei dispôs que são deveres do Poder Público a gestão documental, proteção especial a documentos de arquivos, como instrumento de apoio à administração, à cultura, ao desenvolvimento científico como elementos de prova e informação ${ }^{13}$.

patrimônios documentais que estavam desaparecidos". Cf. UNESCO. Memória do mundo: diretrizes para a salvaguarda do patrimônio documental mundial. Disponível em: <http://mow.arquivonacional.gov.br/images/pdf/Diretrizes_para_a_salvaguarda_do_patrim\%C3\%B4nio_do cumental.pdf>. Acesso em: 12 nov. 2016.

${ }^{11}$ Reza Carlos Henrique Abrão que o Judiciário "ainda não se encontra completamente preparado e com os meios disponíveis para conviver com o subsídio revolucionário. A adaptação, porém, é essencial, com parâmetros, normas e regras que doravante disciplinarão o mecanismo de funcionamento do processo eletrônico". Cf. ABRÃO, Carlos Henrique. Processo eletrônico: Lei n 11.419 de 19 de dezembro de 2006. 2. ed. São Paulo: Revista dos Tribunais, 2009. p. 16.

12 BRASIL. Constituição Federal. Diário Oficial da União, Brasília, DF, 5 out. 1988. Disponível em: <http://www.planalto.gov.br/ccivil_03/constituicao/constituicao.htm>. Acesso em: 15 ago. 2016.

13 “Art. $1^{\circ}$. É dever do Poder Público a gestão documental e a proteção especial a documentos de arquivos, 
Onze anos após a edição daquela lei, o Decreto $n^{\circ} 4.073 / 2002$ veio regrar o SINAR, que é o Sistema Nacional de Arquivos, e que conta com o Poder Judiciário como integrante, além do Conselho Nacional de Arquivos (CONARQ) ${ }^{14}$. Com efeito, tal decreto veio para disciplinar as disposições contidas na Lei $\mathrm{n}^{\circ}$ 8.159/1991.

A produção normativa do CONARQ é essencial para se vislumbrar os caminhos da preservação documental. Uma das mais importantes resoluções editadas pelo referido conselho foi a Resolução $n^{\circ} 26$, de 06 de maio de $2008^{15}$, com redação dada pela Resolução $n^{\circ} 30$, de 23 de

como instrumento de apoio à administração, à cultura, ao desenvolvimento científico e como elementos de prova e informação". Cf. BRASIL. Lei n 8.159, de janeiro de 1991. Dispõe sobre a política nacional de arquivos públicos e privados e dá outras providências. Diário Oficial da República Federativa do Brasil, Brasília, 9 jan. 1991. Disponível em: <http://www.planalto.gov.br/ccivil_03/LEIS/L8159.htm>. Acesso em: 15 ago. 2016.

14 “Art. 10. O SINAR tem por finalidade implementar a política nacional de arquivos públicos e privados, visando à gestão, à preservação e ao acesso aos documentos de arquivo. Art. 11. O SINAR tem como órgão central o CONARQ. Art. 12. Integram o SINAR: I - o Arquivo Nacional; II - os arquivos do Poder Executivo Federal; III - os arquivos do Poder Legislativo Federal; IV - os arquivos do Poder Judiciário Federal; V - os arquivos estaduais dos Poderes Executivo, Legislativo e Judiciário; VI - os arquivos do Distrito Federal dos Poderes Executivo, Legislativo e Judiciário; VII - os arquivos municipais dos Poderes Executivo e Legislativo. § 10 Os arquivos referidos nos incisos II a VII, quando organizados sistemicamente, passam a integrar o SINAR por intermédio de seus órgãos centrais". Cf. BRASIL. Decreto $n^{\circ} 4.073$, de 3 de janeiro de 2002. Regulamenta a Lei $n^{\circ} 8.159$, de 8 de janeiro de 1991, que dispõe sobre a política nacional de arquivos públicos e privados. Diário Oficial da República Federativa do Brasil, Brasília, 4 jan. 2002. Disponível em: <http://www.planalto.gov.br/ccivil_03/decreto/2002/d4073.htm>. Acesso em: 15 ago. 2016.

15 “Art. $1^{\circ}$. Os órgãos do Poder Judiciário relacionados no art. 92, inciso II e seguintes da Constituição Federal de 1988 e os Conselhos respectivos deverão adotar o Programa de Gestão de Documentos do Conselho Nacional de Justiça - CNJ. (Redação dada pela Resolução $n^{\circ} 30$ ). $\S 1^{\circ}$. A adoção do referido Programa de Gestão de Documentos será coordenado por Comitês Gestores, que terão por objetivo zelar pelo cumprimento das diretrizes do referido Programa de Gestão de Documentos e elaborar Planos de Classificação de Documentos e Tabelas de Temporalidade e Destinação de Documentos a serem aplicados nos órgãos de seu âmbito de atuação. (Redação dada pela Resolução $n^{\circ} 30$ ). $§ 2^{\circ}$. Os Comitês Gestores encaminharão à sessão administrativa dos órgãos referidos no art. $1^{\circ}$ os instrumentos de gestão documental específicos para aprovação. (Redação dada pela Resolução $n^{\circ} 30$ ). Art. $2^{\circ}$. Nos órgãos mencionados no art. $1^{\circ}$. e nos demais órgãos da Justiça que os integram serão constituídas Comissões Permanentes de Avaliação de Documentos, que terão responsabilidade de orientar e realizar o processo de análise, avaliação e seleção dos documentos produzidos e recebidos nos respectivos órgãos, tendo em vista a destinação dos documentos para a guarda permanente e a eliminação dos destituídos de valor. Parágrafo Único. Os presidentes das Comissões Permanentes de Avaliação de Documentos integrarão os respectivos Comitês Gestores constituídos nos órgãos referidos no art. $1^{\circ}$. desta resolução. Art. $3^{\circ}$. Caberá à autoridade competente de cada órgão, autorizar a eliminação de documentos, fazendo publicar nos Diários Oficiais da União, do Distrito Federal e dos Estados, correspondentes ao seu âmbito de atuação, os editais para eliminação de documentos, consignando um prazo de 45 dias para possíveis manifestações das partes interessadas. Art. $4^{\circ}$. Os órgãos do Poder Judiciário, por meio de seus Comitês Gestores, promoverão troca de informações sobre experiências e compartilharão esforços de pesquisa e estudo com o objetivo de disseminar as melhores práticas e de unificar padrões de gestão de documentos". Cf. BRASIL. Arquivo Nacional. Resolução CONARQ $n^{\circ}$ 26, de 06 de maio de 2008. Estabelece diretrizes básicas de gestão de documentos a serem adotadas nos arquivos do Poder Judiciário. Disponível em: <http:/ / www.conarq.arquivonacional.gov.br/legislacao/resolucoes-do-conarq/268-resolucao-n-26,-de-06de-maio-de-2008.html>. Acesso em: 15 ago. 2016. 
ELAINE HARZHEIM MACEDO RENAN MATHEUS MACEDO TOLFO

dezembro de 2009. No expediente, o Conselho Nacional de Arquivos estabeleceu que os órgãos do Poder Judiciário, relacionados no art. 92, incisos II e seguintes da Constituição Federal de 1988, além dos Conselhos respectivos, deveriam adotar programa próprio do Conselho Nacional de Justiça, que foi regulamentado em 15 de agosto de 2011, pela Recomendação $n^{\circ} 37^{16}$. Vale lembrar que as normas específicas sobre preservação documental ainda têm aplicação subsidiária ${ }^{17}$.

O acontecimento foi marcante, eis que a partir desse momento aqueles órgãos do Poder Judiciário passaram a receber orientações de gestão de seus arquivos pelo Conselho Nacional de Justiça, ressalvadas algumas observações previstas na referida resolução. Isso tornou mais cristalino o campo de abrangência da política documental, que estrategicamente deve estar delineada por todo o ciclo vital dos documentos, porquanto há três fases que correspondem ao ciclo vital dos documentos institucionais dos órgãos que compõem o Poder Judiciário.

A primeira fase, chamada corrente, diz respeito à própria unidade onde são produzidos e guardados tais arquivos. Aqui, é irrelevante se tais arquivos estão ou não em tramitação, eis que um dos traços marcantes desses documentos é de que estão em constante produção e

${ }^{16}$ BRASIL. Conselho Nacional de Justiça. Recomendação $\mathrm{n}^{\circ}$ 37, de 15 de agosto de 2011. Recomenda aos
Tribunais a observância das normas de funcionamento do Programa Nacional de Gestão Documental e Memória do Poder Judiciário - Proname e de seus instrumentos. Disponível em: <http://www.cnj.jus.br/images/stories/docs_cnj/recomendacoes/reccnj_37.pdf>. Acesso em: 15 ago. 2016.

17 Além disso, vale transcrever as demais responsabilidades elencadas no Moreq-Jus, v.g. "Lei $\mathrm{n}^{\circ}$ $8.159 / 1991$ - Art. 25. Ficará sujeito à responsabilidade penal, civil e administrativa, na forma da legislação em vigor, aquele que desfigurar ou destruir documentos de valor permanente ou considerado como de interesse público e social. Lei $\mathrm{n}^{\circ}$ 9.605/1998 - Art. 62. Destruir, inutilizar ou deteriorar: I - bem especialmente protegido por lei, ato administrativo ou decisão judicial; II - arquivo, registro, museu, biblioteca, pinacoteca, instalação científica ou similar protegido por lei, ato administrativo ou decisão judicial: Pena - reclusão, de um a três anos, e multa. Parágrafo único. Se o crime for culposo, a pena é de seis meses a um ano de detenção, sem prejuízo da multa. Código Penal - Art. 153 - Divulgar alguém, sem justa causa, conteúdo de documento particular ou de correspondência confidencial, de que é destinatário ou detentor, e cuja divulgação possa produzir dano a outrem: Pena - detenção, de um a seis meses, ou multa. $\S 1^{\circ}$ Somente se procede mediante representação. (Parágrafo único renumerado pela Lei $n^{\circ}$ $9.983 / 2000) \S 1^{\circ}$ - A. Divulgar, sem justa causa, informações sigilosas ou reservadas, assim definidas em lei, contidas ou não nos sistemas de informações ou banco de dados da Administração Pública: (Incluído pela Lei $n^{\circ}$ 9.983/2000) Pena - detenção, de 1 (um) a 4 (quatro) anos, e multa. (Incluído pela Lei ${ }^{\circ}$ 9.983/2000) § $2^{\circ}$ Quando resultar prejuízo para a Administração Pública, a ação penal será incondicionada. (Incluído pela Lei $n^{\circ}$ 9.983/2000) Art. 154 - Revelar alguém, sem justa causa, segredo, de que tem ciência em razão de função, ministério, ofício ou profissão, e cuja revelação possa produzir dano a outrem: Pena detenção, de três meses a um ano, ou multa. Parágrafo único - Somente se procede mediante representação. Lei $n^{\circ}$ 9.296/1996 - Art. 10. Constitui crime realizar interceptação de comunicações telefônicas, de informática ou telemática, ou quebrar segredo da Justiça, sem autorização judicial ou com objetivos não autorizados em lei. Pena: reclusão, de dois a quatro anos, e multa". Cf. BRASIL. Conselho Nacional de Justiça. Manual de gestão documental. Disponível em: <http://www.cnj.jus.br/images/ programas/gestaodocumental/manual_gestao_documental_poder\%20judiciario.pdf>. Acesso em: 15 ago. 2016. 
ISSN 1981-3694

(DOI): 10.5902/1981369425362

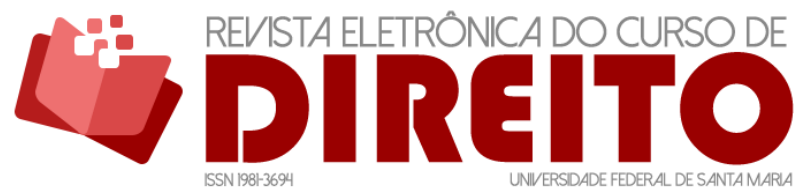

DO PROCESSO ELETRÔNICO AO DOCUMENTO PÚBLICO: UMA ANÁLISE DA CONSERVAÇÃO DOS AUTOS COMO ARQUIVOS

PERMANENTES

ELAINE HARZHEIM MACEDO RENAN MATHEUS MACEDO TOLFO

consulta. Nessa fase, as unidades onde estão sendo produzidos os documentos devem gerir até o devido envio ao arquivo centralizado. Falando em termos processuais, esta fase se dá desde a instauração do processo (petição inicial, denúncia, etc.) até o seu encerramento, quando vencidas todas as possíveis etapas subsequentes, como fase recursal, ou, em termos de processo civil, cumprimento definitivo da sentença, quando não mais manuseados pelos possíveis interessados. Este é o momento em que os autos do processo não mais servem ao processo, deixando de serem tratados à luz da legislação processual (CPC, CPP ou quaisquer outras regras processuais inseridas em legislações específicas, como CLT, legislação eleitoral, ECA, etc.), voltada ao iter procedimental, passando a constituírem documento público, submetendo-se exclusivamente à legislação arquivística. De sorte que no período conhecido como "arquivos correntes", há duas legislações coincidentes a incidir sobre a documentação levada a efeito: a legislação processual propriamente dita, que determina a forma e o andamento dos atos processuais, e - lamentavelmente no mais das vezes olvidada - a legislação que cuida da preservação dos documentos, quando, em futuro próximo, apenas essa última deverá prevalecer. Ambos os diplomas contam com sua função precípua e devem ser observados, sem qualquer hierarquia de valor. Um, destinado à função jurisdicional, outro, à memória da vida pública e privada que é contada nos autos.

De outra banda, a fase intermediária se dá quando inserido o documento no arquivo centralizado para onde deva convergir, sendo que lá aguardará sua destinação final, visto ser esta a unidade administrativa que possui a responsabilidade de armazenar e administrar os documentos com origem processual enquanto aguardam a eliminação ou o recolhimento para o arquivo permanente, que será a última fase do ciclo vital do documento. Nesse arquivo central será gerenciada a documentação, seja na segunda ou terceira fase. No que toca à segunda, nele aguardarão o cumprimento das disposições de prazos com fulcro na sua destinação final.

Por último, conhecida por fase permanente, essa se traduz na guarda da documentação, reconhecida como patrimônio histórico e arquivístico da instituição. Os instrumentos de gestão arquivísticas são muito bem-vindos na efetiva seleção dos documentos que irão para a guarda permanente, eis que a seleção com base em critérios normativos estabelecidos pela Comissão de Avaliação, como o corte cronológico e a guarda amostral, são alguns exemplos dos utilizados quando da captura do documento para a terceira fase.

Um dos enfoques principais que toca ao arquivo permanente é a reunião e o tratamento dos documentos após a finalização da sua função primária, que é o uso imediato do órgão produtor e de seus destinatários. Após a chamada função primária, tais documentos 
ELAINE HARZHEIM MACEDO RENAN MATHEUS MACEDO TOLFO

permanentes possuem o condão de servir para outras funções da administração e sociedade, já que são ricas fontes de informação e, como visto, refletem a própria história. Já o local em que tais arquivos estarão disponíveis para consulta são chamados de arquivo histórico, lembrando-se, claro, da necessidade de segurança do acesso à informação, além do próprio documento público e permanente. Ademais, convém destacar que os documentos permanentes que fazem parte do fundo arquivístico das instituições do Poder Judiciário não poderão ser eliminados, não importando se digitalizados ou em papel. 0 meio de registro não é relevante, mas sim o conteúdo histórico do documento preservado.

Fruto de resoluções e dos próprios instrumentos do programa do Conselho Nacional de Justiça para o tema, a separação de autos de processos para a guarda permanente deve obedecer a critérios, como o corte cronológico; classes e assuntos; conformidade à Tabela de Temporalidade; seleção pela Comissão Permanente de Avaliação de Documentos (CPAD) e amostra estatística dos processos não selecionados pelos critérios anteriormente elencados, ao efeito de registro histórico por amostragem desses feitos cuja natureza não ganha, de per si, destaque próprio. Em busca de uma legislação mais congruente a respeito da preservação documental, a I CNARQ, em sua plenária final, aprovou propostas relativas à necessidade de revisão e ampliação da Lei $\mathrm{n}^{\circ} 8.159 / 1991^{18}$, dando maior envergadura para o CONARQ e direcionando normas mais abrangentes sobre o tratamento dos documentos.

\footnotetext{
${ }^{18}$ Um dos enfoques é o de reestruturar o Capítulo IV da Organização e Administração de Instituições Arquivísticas Públicas dando-lhe mais precisão; reforçar o dever do Poder Público para com a gestão de documentos, conforme determina o $\$ 2^{\circ}$ do art. 216, da Constituição Federal de 1988; alterar dispositivos das Disposições Gerais para desvincular o CONARQ do Arquivo Nacional, uma vez que grande parte dos conselhos nacionais não é vinculado a órgãos específicos e, sim, a um ministério, dando-lhe estrutura para funcionamento, fortalecendo sua atuação como órgão regulador do setor arquivístico nacional, e autorizar a criação de um fundo nacional de arquivos de apoio à modernização dos arquivos. Em verdade, as propostas de alterações na atual Lei $n^{\circ} 8.159 / 1991$ visam também a organizar o que foi até aqui visto, como é o caso do art. 20, da atual redação: Art. 20 - Competem aos arquivos do Poder Judiciário Federal a gestão e o recolhimento dos documentos produzidos e recebidos pelo Poder Judiciário Federal no exercício de suas funções, tramitados em juízo e oriundos de cartórios e secretarias, bem como preservar [...]. Com efeito, a vinculação do Poder Judiciário Federal aparentemente exclui atualmente os demais poderes estaduais. Contudo, o próprio decreto que, como antes visto veio a disciplinar tal lei, dispôs que integra o Sinar todos os órgãos do Poder Judiciário, excluindo-se o STF. Desta feita, a proposta de alteração prevê: Art. $1^{\circ}$. Parágrafo Único. Prevê subordinação ao regime legal no âmbito da União, dos Estados, do Distrito Federal e dos Municípios os órgãos públicos [...] Judiciário, e do Ministério Público. Claramente a subordinação do Poder Judiciário, inclusive estadual, assim como do Ministério Público está presente. Outrossim, o mesmo art. 20, em sua nova redação, tem como texto: Art. 20. Compete aos arquivos dos órgãos do Poder Judiciário, relacionados no art. 92 da Constituição Federal, e seus respectivos Conselhos: I - gerir e recolher os documentos por eles produzidos e recebidos no exercício das suas funções jurisdicionais e administrativas; II - preservar e garantir o acesso às informações contidas nos documentos previstos no inciso I; $\S 1^{\circ}$ Os órgãos referidos no caput deverão adotar as normas estabelecidas pelo Conselho Nacional de Justiça, observada a política nacional de arquivos. $\S 2^{\circ} 0$ Supremo Tribunal Federal observará a política nacional de arquivos, a ele não se aplicando o disposto no $\S$
} 
É, de fato, a concretização de todos os dispostos nas resoluções e em nossa Constituição Federal. $0 \$ 1^{\circ}$ demonstra o já disposto na Resolução $n^{\circ} 26$, do CONARQ, que foi trabalhada neste artigo, de que aos órgãos do Poder Judiciário, ressalvado o STF ( $\$ 2^{\circ}$ do Projeto de Lei), que deverá obedecer à Política Nacional de Arquivos, devem ser aplicadas tais políticas. A exclusão do STF não é seu distanciamento das respectivas, que encontra fundamento constitucional, mas sim por força da questão hierárquica, não podendo haver qualquer órgão administrativo ou judiciário que se sobreponha ao Supremo.

Muitos tribunais vêm seguindo a Recomendação $n^{\circ}$ 37/2011 do Conselho Nacional de Justiça para a preservação documental, haja vista os instrumentos do Proname serem fortemente amparados e atuais, dada sua importância, e por serem frutos de uma colaboração intensiva junto ao Conselho Nacional de Arquivos.

Ainda que haja evolução legislativa a respeito, a evolução tecnológica também obrigou os operadores de diversas áreas, como Arquivologia e Direito, a trabalharem na multidisciplinariedade. Como se pôde perceber, muitas são as variáveis que devem ser consideradas para fazer uma preservação documental da maneira correta, o que torna indispensável o acompanhamento de profissionais de outras áreas, especialmente da Arquivologia. Adiante será vislumbrado os avanços dessas duas áreas em prol do dever de preservação documental, já que há um intercâmbio crescente e cada vez mais necessário entre estas nos dias atuais.

\section{A SISTEMÁTICA DA PRESERVAÇÃO DO ARQUIVO DIGITAL}

A racionalização, a modernização e a otimização dos procedimentos do Poder Judiciário para atender ao intenso crescimento das demandas de acordo com as suas competências é também fruto de um desenvolvimento tecnológico. Diz-se que a instituição do Programa Nacional de Gestão Documental e Memória do Poder Judiciário (Proname) pelo Conselho Nacional de Justiça tem como ideia central a implantação da política nacional de gestão documental e de preservação da memória dos diversos órgãos do judiciário brasileiro. No ponto, as suas ações são voltadas à integração dos tribunais, à padronização e utilização das melhores

$1^{\circ}$.Nessa publicação encontra-se disponível o memorial de todo o processo e os resultados alcançados pela I Conferência Nacional de Arquivos - CNARQ. Disponível em: $<$ http://www.conarq.arquivonacional.gov.br/images/publicacoes_textos/cnarq/Relatorio_final_com_capa .pdf>. Acesso em: 27 out. 2016. E, ainda, os anexos, disponíveis em: <http://www.conarq.arquivonacional.gov.br/images/publicacoes_textos/cnarq/Anexos.pdf>. Acesso em: 27 out. 2016. 
práticas de gestão documental, de modo a possibilitar a preservação e acessibilidade das informações contidas nos autos judiciais e em documentos institucionais administrativos, com fulcro no aperfeiçoamento da prestação dos serviços jurisdicionais e administrativos do Poder Judiciário.

O Modelo de Requisitos para Sistemas Informatizados de Gestão de Processos e Documentos do Judiciário brasileiro (MoReq-Jus) é fruto de um grupo de trabalho interdisciplinar integrado por especialistas das áreas de Ciência da Informação, Tecnologia da Informação e do Direito, aqui se incluindo servidores e magistrados, e adveio da imperativa necessidade de se estabelecer requisitos mínimos para os sistemas informatizados do Poder Judiciário, a fim de dar a confiabilidade, a autenticidade e a acessibilidade necessária aos documentos e processos geridos por esses sistemas ${ }^{19}$.

O MoReq-Jus foi aprovado pela Resolução $n^{\circ}$ 7, do Conselho da Justiça Federal, de 7 de abril de 2008, e disciplinou a obrigatoriedade de sua utilização no desenvolvimento de novos sistemas informatizados para as atividades judiciárias e administrativas, no âmbito do Conselho e da Justiça Federal de primeiro e segundo graus. Foi um importante avanço, eis que os sistemas não conversavam entre si. A partir do sucesso de sua aplicação, o CNJ o utilizou como referência para os demais órgãos do Poder Judiciário, nos seus diferentes âmbitos. Ora, era preciso estabelecer uma linguagem padrão, assim como o idioma oficial no país é o português, era necessário referenciar um modelo ideal de sistema que pudesse garantir a efetiva realização dos primados fundamentais da cadeia arquivista e, obviamente, constitucional. Neste quesito bem

19 "O Modelo de Requisitos para Sistemas Informatizados de Gestão de Processos e Documentos do Judiciário brasileiro (MoReq-Jus) estabelece condições a serem cumpridas na produção, na tramitação, na guarda, no armazenamento, na preservação, no arquivamento ou no recebimento de documentos, pelos sistemas de gestão de processos e documentos digitais, não-digitais ou híbridos, a fim de garantir a sua confiabilidade e autenticidade, assim como o seu acesso. O MoReq-Jus estabelece processos e requisitos mínimos para um Sistema Informatizado de Gestão de Processos e Documentos (GestãoDoc), independentemente da plataforma tecnológica em que for desenvolvido e implantado. Um GestãoDoc deve ser capaz de gerenciar simultaneamente os documentos e processos digitais, não-digitais e híbridos. Para os documentos não-digitais, o sistema registra apenas as referências a esses documentos e as operações de produção, de tramitação, de guarda, de armazenamento, de preservação, de arquivamento e de recebimento. No caso dos sistemas de documentos digitais, este registra os documentos e as operações mencionadas. A produção de documentos digitais levou à criação de sistemas de gerenciamento de documentos. Entretanto, para assegurar que documentos digitais sejam confiáveis e autênticos e que possam ser preservados com essas características, é fundamental que esses sistemas incorporem os conceitos arquivísticos e suas implicações no gerenciamento dos documentos digitais". Cf. BRASIL. Conselho Nacional de Justiça. Modelo de Requisitos para Sistemas Informatizados de Gestão de Processos e Documentos do Judiciário brasileiro - MoReq-Jus. Disponível em: <http://www.cnj.jus.br/images/programas/gestao-documental/rescnj_91.pdf>. Acesso em: 15 ago. 2016. 
apontada crítica de Tarcísio Teixeira, quando se referiu à falha da Lei $\mathrm{n}^{\circ} 11.419$ em permitir cada Tribunal criar seu sistema individualizado ${ }^{20}$.

No ponto, o Poder Judiciário conta com duas dificuldades distintas: administrar um passivo quase secular de documentos oriundos de um processo produzido em papel, por anos e anos não gerenciado ou mal gerenciado, acumulando-se os autos em espaços e prateleiras encarados como mero depósito, e documentos produzidos por sistemas informatizados variados, servindo-se de tecnologias que vêm se sobrepondo no tempo e sujeitas a profundas modificações, até porque ainda não temos, em território nacional, um sistema de e-processo comum a todas as áreas judiciárias.

Cabe anotar o avanço percebido nos últimos anos em Tribunais brasileiros, e não apenas cotejando o processo judicial, mas também o administrativo, por também estarem abrangidos pelas normas de preservação documental. O Tribunal Regional Federal da $4^{\text {a }}$ Região instituiu o SEI (Sistema Eletrônico de Informações) que é um sistema eletrônico de gestão do conhecimento online, sem o uso do papel. Esse projeto foi colocado em prática, e seus reflexos foram muito positivos, sendo sua plataforma tornada referência no país e utilizada também pela Prefeitura de São Paulo, Supremo Tribunal Federal, Conselho Nacional de Justiça, Defensoria Pública da União, dentre muitas outras instituições ${ }^{21}$. Além de agilizar a tramitação dos processos administrativos, o referido fundamenta-se na sustentabilidade e economia na administração pública, de modo que possibilitou, a partir de uma ferramenta colaborativa e livre, o manuseio dos processos administrativos dos Tribunais, garantindo-se em princípios de preservação 22 .

$\mathrm{Na}$ sistemática a ser obedecida para a correta preservação documental, têm-se requisitos que devem ser cumpridos a fim de que se possa garantir a autenticidade e a confiabilidade dos documentos. É imprescindível o cumprimento de tais conceitos para que os documentos digitais sejam preservados de forma permanente.

20 "A Lei $\mathrm{n}^{\circ}$ 11.419/2006 ainda falha quando autoriza os tribunais pátrios a criarem individualmente plataformas eletrônicas para a prática de atos processuais. Conforme se verifica, especialmente pelas redações dos arts. $2^{\circ}$ e $8^{\circ}$ da lei, trata-se de medida facultativa aos órgãos do Poder Judiciário adotar um sistema padronizado.”. Cf. TEIXEIRA, Tarcísio. Curso de direito e processo eletrônico: doutrina, jurisprudência e prática. São Paulo: Saraiva, 2013. p. 351.

21 A aplicação do SEl preenche os requisitos adotados para o uso do meio eletrônico no processo administrativo. Cf. BRASIL. Decreto $\mathrm{n}^{\circ} 8.539$, de 8 de outubro de 2015. Dispõe sobre o uso do meio eletrônico para a realização do processo administrativo no âmbito dos órgãos e das entidades da administração pública federal direta, autárquica e fundacional. Diário Oficial da República Federativa do Brasil, Brasília, 9 out. 2015. Disponível em: <http://www.planalto.gov.br/ccivil_03/_Ato20152018/2015/Decreto/D8539.htm>. Acesso em: 12 nov. 2016.

${ }^{22}$ BRASIL. Superior Tribunal Militar. IV Congresso Brasileiro de Arquivos do Poder Judiciário, Brasília, 18, 19 e 20 nov. 2015. Disponível em: <https://www.stm.jus.br/IV-congresso-brasileiro-de-arquivos/>. Acesso em: 12 nov. 2016. 


\subsection{Os requisitos fundamentais da preservação de longo prazo}

No MoReq-Jus ${ }^{23}$, a preservação digital compreende a preservação física, lógica e intelectual dos documentos digitais. Muitas questões são correntes acerca das melhores práticas a serem adotados hoje, até mesmo pelo usuário, ao transmitir seus documentos ${ }^{24}$. A preservação física está focalizada nos conteúdos armazenados em suportes magnéticos, v.g. o cassete VHS, e nos suportes ópticos, v.g. o CD-ROM, que levam à necessidade de definição de regras para a migração dos formatos em que os documentos estão registrados. Desse modo, a preservação lógica busca na tecnologia formatos atualizados para a introdução dos dados.

A busca de métodos de preservação digital requer não somente procedimentos de manutenção e recuperação de dados, no caso de perdas acidentais, para resguardar a mídia e seu conteúdo, mas sobretudo estratégias e procedimentos para manter sua acessibilidade e autenticidade através do tempo, o que demanda a aplicação de padrões de metadados e documentação.

É previsto que a longo prazo, o fracasso na preservação dos documentos digitais acarretará na perda irreversível do registro, da prova, do testemunho, da memória. Mais fácil de ocorrer do que a perda do documento produzido em papel, trauma que vivemos no presente e que deve, sim, dirigir o futuro, guardadas as especificidades, quanto ao documento digital ${ }^{25}$.

${ }^{23}$ BRASIL. Conselho Nacional De Justiça. Modelo de Requisitos para Sistemas Informatizados de Gestão de Processos e Documentos do Judiciário brasileiro - MoReq-Jus. Disponível em: <http://www.cnj.jus.br/images/programas/gestao-documental/rescnj_91.pdf>. Acesso em: 15 ago. 2016.

${ }^{24}$ No IV Congresso Brasileiro de Arquivos do Poder Judiciário, ocorrido em novembro de 2015, no Superior Tribunal Militar, em Brasília, foi abordado por João Alberto de Oliveira Lima, na palestra "Preservação de Documentos Digitais e o Formato PDF/A", acerca dos benefícios de utilização dos arquivos em formato PDF/A. Esses arquivos são livres, e inclusive recomendados pela ISO 19.005-1, em que o foi definido como formato padrão universal de longa duração, eis que possui propriedades que buscam mantê-lo digitalmente íntegro, o que não ocorre com os demais arquivos digitais. Cf. BRASIL. Superior Tribunal Militar. IV Congresso Brasileiro de Arquivos do Poder Judiciário, Brasília, 18, 19 e 20 nov. 2015. Disponível em: <https://www.stm.jus.br/IV-congresso-brasileiro-de-arquivos/>. Acesso em: 12 nov. 2016.

${ }^{25}$ Exemplo de perda de documento com valor histórico, ainda que não total, deu-se nos arquivos do Tribunal de Justiça do Rio Grande do Sul, relativamente ao processo crime conhecido como "processo mãos amarradas", que apurou a responsabilidade criminal de policiais pela prisão, tortura e morte do ativista político e do ex-sargento Manoel Raimundo Soares. Os respectivos autos, considerando a época em que os fatos aconteceram documentados em papel, foram encontrados no arquivo em lamentável estado de deterioração em razão do tempo e mau acondicionamento, recuperados parcialmente, ainda que utilizada técnica altamente qualificada, porque parte do documento estava literalmente esfacelada e impossível de ser restaurada. Hoje os documentos integram o Memorial do Tribunal de Justiça do Rio Grande do Sul. DOCUMENTO histórico: Peças do processo crime mãos amarradas: denúncia e habeas corpus. Direito e democracia, Universidade Luterana do Brasil, v. 6, n. 2, $2^{\circ}$ sem. 2005. Canoas: Ulbra, 2005, p. 513-522. 
Desse modo, a questão da preservação pode ter um impacto negativo na memória coletiva, pública e privada da sociedade, com repercussão em questões legais, comerciais e organizacionais.

No Poder Judiciário, com massiva produção de documentos e processos em meio digital, torna-se premente a definição de estratégias com fulcro na preservação, a regulamentação de questões associadas ao valor probatório, a uniformização de procedimentos definidos normativamente e a definição de parâmetros para a certificação de qualidade. Pode-se dizer que a evolução tecnológica demanda não apenas a conservação do meio físico em que a informação se encontra, mas admitindo os novos suportes - que são os meios de armazenamento -, deve-se melhor adequar a informação nesses, conforme exposto pelo arquivista canadense Terry Cook ${ }^{26}$ na obra Archival Science and Postmodernism: New Formulations for Old Concepts.

Além disso, as questões que envolvem a preservação digital não estão restritas somente à seleção do que se preservar, mas também garantir a confiabilidade, a autenticidade e a acessibilidade dos documentos e processos geridos pelos sistemas informatizados do Judiciário brasileiro. Não basta preservar, é preciso ter a certeza de que se trata de documento autêntico, apto, portanto, a ser considerado como documento histórico.

Como exposto no artigo Archivematica uma Ferramenta de Software livre para preservação de documentos arquivísticos digitais, uma instituição que pretende assumir a responsabilidade de preservar informação digital por longo prazo precisa - como é o caso do Poder Judiciário - observar inicialmente alguns conceitos, tais como (a) Gestão arquivística de documentos: definir procedimentos e estratégias de gestão arquivística de documentos quando da criação, transmissão e preservação de documentos em formatos digitais, com o objetivo de garantir a produção e manutenção de documentos fidedignos, autênticos, acessíveis, compreensíveis e preserváveis; (b) Padrões e protocolos: definir a utilização de padrões e protocolos abertos e de aceitação ampla na criação, uso, transmissão e armazenamento de documentos digitais; (c) Requisitos funcionais: definir os requisitos funcionais e estimular sua adoção para orientar o desenvolvimento e a aquisição de sistemas eletrônicos de gestão arquivística, que se adequem às especificidades da legislação e das práticas arquivísticas brasileiras; (d) Localizar e rastrear o objeto digital ao longo do tempo: imediatamente após a

26 "Preservation will, as noted before, no longer focus on repairing, conserving, and safeguarding the physical medium that was the record, but instead concentrate on continually migrating or emulating the concepts and interrelationships that now define virtual records and virtual fonds to new software programmes". Cf. COOK, Terry. Archival Science and Postmodernism: new formulations for old concepts. Archival Science, v. 1, p. 13-24, 2000. Disponível em: <http://www.mybestdocs.com/cook-t-postmod-p100.htm>. Acesso em: 12 nov. 2016. 
sua criação, os objetos digitais tornam-se passíveis de serem alterados, copiados ou movimentados. Em qualquer referência ao objeto digital, é necessário localizá-lo na edição ou versão correta; (e) Preservar a proveniência: identificar a origem de um objeto e detalhar seu histórico ajuda a confirmar sua autenticidade e integridade; (f) Definir política de segurança da informação, que considere os aspectos legais, organizacionais, humanos e tecnológicos, de modo a garantir a autenticidade dos documentos digitais e o sigilo da informação, bem como a proteção contra perdas, acidentes e intervenções não autorizadas ${ }^{27}$.

\subsection{Da seleção de documentos}

A avaliação é a função arquivística que trata da análise dos valores atribuídos aos documentos, sejam eles primários e secundários. Como valor primário, tem-se as razões de sua própria produção, de modo a considerar seu uso para fins administrativos, legais e fiscais. Já o valor secundário está para o respeito à potencialidade de o documento se voltar a servir como prova ou fonte de informação para a pesquisa. A análise desses valores permite a definição dos prazos de guarda e da destinação final da informação, pela eliminação ou recolhimento ${ }^{28}$. Assim, é a partir da avaliação que se determina a destinação do documento dentro da instituição. Os prazos de guarda e as ações de destinação (eliminação ou guarda permanente) são estipulados de forma mínima nos instrumentos de classificação, temporalidade e destinação do Proname, estando os documentos produzidos sujeitos à avaliação pelas Comissões Permanentes de Avaliação Documental, que possuem dentre as suas atribuições a de verificar se é caso de aumentar a temporalidade ou alterar a destinação de eliminação para permanente. Ainda, é importante esclarecer que avaliação dos documentos administrativos deverá seguir os critérios do Plano de Classificação e Tabela de Temporalidade dos Documentos da Administração do Poder Judiciário $^{29}$.

27 COSTA, Milene Aparecida Silva da; CASTRO, Priscila de Paiva. Archivematica uma Ferramenta de Software livre para preservação de documentos arquivísticos digitais. Revista Intercâmbio dos Congressos Internacionais de Humanidades, Brasília, n. 6, p. 106-119, 2016. Disponível em: <http://unb.revistaintercambio.net.br/24h/pessoa/temp/?file=anexo, 1,11625, 3008,3008.Archivematica\%2 Ouma\%20Ferramenta\%20de\%20Software\%20livre\%20para\%20preserva\%C3\%A7\%C3\%A3o\%20de\%20documentos \%20arquiv\%C3\%ADsticos\%20digitais>. Acesso em: 15 ago. 2016.

28 BRASIL. Conselho Nacional de Justiça. Manual de Gestão Documental. Disponível em: <http://www.cnj.jus.br/images/programas/gestaodocumental/manual_gestao_documental_poder\%20judi ciario.pdf>. Acesso em: 15 ago. 2016.

29 BRASIL. Conselho Nacional de Justiça. Manual de Gestão Documental. Disponível em: <http://www.cnj.jus.br/images/programas/gestaodocumental/manual_gestao_documental_poder\%20judi ciario.pdf>. Acesso em: 15 ago. 2016. 
Como dispõe o Manual de Gestão Documental elaborado pelo Conselho Nacional de Justiça, os processos judiciais serão classificados de acordo com as Tabelas Processuais Unificadas do Poder Judiciário criadas pelo CNJ (instrumento do Proname previsto no item IV, “b”, da Recomendação n. 37/2011 do CNJ). Com efeito, o CNJ buscou seguir as recomendações da Carta da UNESCO para a Preservação do Patrimônio Arquivístico Digital, com fulcro em minimizar os efeitos da fragilidade e da obsolescência de hardware, software e formatos, de modo a permitir, ao longo do tempo, o acesso contínuo e o uso da informação a todos os segmentos da sociedade ${ }^{30}$. As tabelas em questão são de observância obrigatória pelos órgãos do Poder Judiciário. O Plano de Classificação instituído pelas Tabelas Processuais Unificadas do Poder Judiciário constitui instrumento de gestão documental que padroniza a classificação dos documentos jurisdicionais. As Tabelas Processuais Unificadas para o Poder Judiciário são as seguintes: (a) Tabela de Assuntos Processuais - trata do direito material e é utilizada para padronizar nacionalmente o cadastramento das matérias ou temas discutidos nos processos; (b) Tabela de Classes Processuais - trata do procedimento judicial adequado ao pedido; (c) Tabela de Movimentos Processuais - trata do registro dos procedimentos e rotinas dos atos processuais que impulsionam o processo ${ }^{31}$.

A Tabela de Temporalidade dos Processos Judiciais do Poder Judiciário e a Tabela de Temporalidade dos Documentos da Administração do Poder Judiciário constituem instrumentos de gestão documental que apontam a guarda permanente para os documentos previamente indicados com tal atributo ou a temporalidade mínima de guarda aplicável aos documentos produzidos por este Poder, tanto na atuação judicial e administrativa. Busca-se a recomendação de utilização das Tabelas de Temporalidade do Poder Judiciário disponíveis no portal do Conselho Nacional de Justiça por todos os seus órgãos. Outrossim, temporalidade dos processos judiciais está indicada na Tabela de Temporalidade Documental Unificada (TTDU) aprovada pelo Conselho Nacional de Justiça ${ }^{32}$. Com efeito, repisa-se que para a gestão documental é sugerida, de acordo com o item III, "g", da Recomendação n 37/2011, do CNJ, que sejam constituídas

30 UNESCO. A memória do mundo na era digital: digitalização e preservação. Disponível em: $<$ http://www.unesco.org/new/fileadmin/MULTIMEDIA/HQ/Cl/Cl/images/mow/unesco_ubc_vancouver_de claration_pt.pdf>. Acesso em: 14 nov. 2016.

31 BRASIL. Conselho Nacional de Justiça. Manual de Gestão Documental. Disponível em: <http://www.cnj.jus.br/images/programas/gestaodocumental/manual_gestao_documental_poder\%20judi ciario.pdf>. Acesso em: 15 ago. 2016.

32 BRASIL. Conselho Nacional de Justiça. Manual de Gestão Documental. Disponível em: <http://www.cnj.jus.br/images/programas/gestaodocumental/manual_gestao_documental_poder\%20judi ciario.pdf>. Acesso em: 15 ago. 2016. 
unidades de gestão documental e de comissões permanentes de avaliação documental (CPADs), consoante disposto no MoReq-Jus.

O Tribunal Regional Federal da $4^{\text {a }}$ Região já consegue dar singular efetividade àqueles primados constitucionais, garantindo a preservação e o acesso à informação preservada. Com base em normas nacionais e internacionais de descrição arquivística, as informações descritivas do Fundo, Seções, Séries, Processos e Itens Documentais apresentam-se disponíveis no software ATOM, de maneira livre, possibilitando a qualquer usuário da rede mundial de computadores ter acesso ao sistema, em que poderá pesquisar processos e encontrar, por exemplo, digitalizações de petições históricas no âmbito daquele Tribunal, possuindo também arquivos preservados da justiça de primeiro grau ${ }^{33}$. A análise desses valores torna possível a definição dos prazos de guarda e da destinação final da informação: eliminação ou recolhimento. É a partir da avaliação que se determina a destinação do documento dentro da instituição. Todo o processo de avaliação documental, do que deve ou não ser preservado, precisa ocorrer num ambiente que propicie as ferramentas necessárias de modo a cumprir os primados arquivísticos. Da necessidade de se encontrar um sistema que conseguisse se comunicar com a produção da seleção documental e, também, com outros sistemas que pudessem dar acesso aos documentos selecionados, adveio a busca por um Repositório Arquivístico Digital Confiável.

\subsection{Do Archivematica como Repositório Arquivístico Digital Confiável}

A resolução $n^{\circ} 43$ de 4 de setembro de 2015 fundou as diretrizes direcionadas à implementação de repositórios arquivísticos digitais confiáveis para gerir documentos arquivísticos digitais para o Sistema Nacional. No ponto, o Conarq estabeleceu que: "um repositório arquivístico digital confiável (RDC-Arq) deve ser capaz de atender aos procedimentos arquivísticos em suas diferentes fases e aos requisitos de um repositório digital confiável"34.

\footnotetext{
${ }^{33}$ Conforme consta do sítio oficial, "o Fundo Justiça Federal de Primeiro Grau do Rio Grande do Sul é composto pelos documentos produzidos e recebidos pela Justiça Federal no desempenho de suas atividades no Estado do Rio Grande do Sul. São processos judiciais e documentos administrativos, em suportes físicos e eletrônicos, que registram o funcionamento e prestação da justiça. A gestão dos documentos permite sua identificação, organização, acesso e principalmente a preservação da memória institucional e social. Por meio da descrição dos documentos de valor histórico e informativo, a Justiça Federal do RS procura dar visibilidade e difundir as informações aos pesquisadores e à sociedade". RIO GRANDE DO SUL. Justiça Federal. Acervo Histórico. Disponível em: <https://www2.jfrs.jus.br/acervohistorico/>. Acesso em: 14 nov. 2016.

${ }^{34}$ COSTA, Milene et al. Guia do usuário Archivematica. Brasília: Instituto Brasileiro de Informação em Ciência e Tecnologia, 2016. Disponível em: <http://livroaberto.ibict.br/bitstream/123456789/1063/4/Manual-Archivematica.pdf>. Acesso em: 12
} 
Assim, o RDC-Arq é um sistema voltado para preservação e acesso, pelo tempo que se fizerem necessários, direcionados a documentos de cunho arquivístico digitais. 0 diferencial de tal sistema é que ele é capaz de atender aos procedimentos preconizados pela Arquivologia nas idades corrente, intermediária e permanente, e aos requisitos de um repositório digital confiável ${ }^{35}$.

Desse modo, um RDC-Arq constitui-se então em um Ambiente de Preservação e acesso, no Arquivo Permanente Digital das instituições, sendo fundamental sua adoção, porquanto é direcionado a gerenciar os documentos e metadados de acordo com os princípios e as práticas da Arquivologia, especificamente relacionados à gestão documental, descrição arquivística multinível e preservação; proteger as características do documento arquivístico, em especial a autenticidade (identidade e integridade) e a relação orgânica; preservar e dar acesso, pelo tempo necessário, a documentos arquivísticos digitais autênticos; e estar em conformidade com a ISO 16363:2012, que lista os critérios a que um repositório digital confiável deve atender, conforme o Guia do Usuário - Archivematica, produzido pelo Instituto Brasileiro de Informação e Tecnologia ${ }^{36}$.

Importante trabalho vem sendo desenvolvido por grupo de pesquisa vinculado ao CNPq, pela Universidade Federal de Santa Maria, sobre esse problema, talvez o mais sério de todos, que consiste na preservação adequada de documentos digitais produzidos nas mais diversas mídias eletrônicas, tendo por objeto o estudo de um sistema de preservação digital gratuito e de código aberto, isto é, software livre, exatamente ao escopo de manter o livre acesso, preservando-se no tempo a memória digital, denominado Archivematica, sistema esse que é desenvolvido e empacotado com o gerenciador de conteúdo AtoM (ICA-AtoM), baseado na Web para acesso aos documentos digitais, conforme ensina Daniel Flores.

O Archivematica é um ambiente de preservação digital de software livre, gratuito e de código aberto criado para manter os dados baseados em padrões de preservação digital e o acesso em longo prazo para coleções de objetos digitais. Além disso, pode-se dizer que o Archivematica é desenvolvido com o gerenciador de conteúdo AtoM, sistema baseado na Web

nov. 2016. p. 10.

${ }^{35}$ COSTA, Milene et al. Guia do usuário Archivematica. Brasília: Instituto Brasileiro de Informação em Ciência e Tecnologia, 2016. Disponível em: <http://livroaberto.ibict.br/bitstream/123456789/1063/4/Manual-Archivematica.pdf >. Acesso em: 12 nov. 2016. p. 10.

${ }^{36}$ COSTA, Milene et al. Guia do usuário Archivematica. Brasília: Instituto Brasileiro de Informação em Ciência e Tecnologia, 2016. Disponível em: <http://livroaberto.ibict.br/bitstream/123456789/1063/4/Manual-Archivematica.pdf>. Acesso em: 12 nov. 2016. p. 11. 
para acesso aos seus objetos digitais, reconhecido arquivisticamente como uma plataforma de descrição, difusão e acesso ${ }^{37}$.

Deve ser pontuado que o Archivematica usa um padrão de design de microsserviços para fornecer um conjunto integrado de ferramentas de software que permite ao usuário processar objetos digitais, de ingerir para o acesso em conformidade com o modelo funcional ISO-OAIS. 0 Usuário monitora e controla os microsserviços através de um painel baseado na web. Além disso, o Archivematica usa Mets, Premis (eventos, agentes, direitos e restrições), Dublin Core, da Biblioteca do Congresso, especificação Baglt e outros padrões e práticas para fornecer pacotes de arquivamento confiáveis, autênticos e interoperáveis (AIP) para o armazenamento em prática no seu repositório preferido ${ }^{38}$.

Ademais, o Archivematica dispõe de um conjunto integrado de ferramentas livres e de código aberto que permite aos usuários processar objetos digitais para armazenamento de arquivos e acesso em conformidade com a ISO-OAIS modelo funcional e de outras normas de preservação digital e as melhores práticas. Além disso, todo o código Archivematica é liberado sob a licença GNU Affero General Public License e a documentação Archivematica é liberada sob uma Creative Commons Atribuição-Compartilhamento pela mesma Licença 4.0 Internacional ${ }^{39}$. 0 Archivematica faz integração com vários sistemas de acesso e armazenamento, como AtoM, CONTENTdm, Archivist's Toolkit, DSpace, LOCKSS, Duracloud, Arkivum, conforme disposto em seu Guia ${ }^{40}$.

Cabe esclarecer que quando se fala de Plataformas Digitais ou Ambientes em uma Cadeia de Custódia Arquivística, encontram-se três sistemas trabalhando em conjunto. Temos, primeiramente, o Ambiente de Gestão de Documentos (Sigad); como segunda plataforma, o

${ }^{37}$ COSTA, Milene et al. Guia do usuário Archivematica. Brasília: Instituto Brasileiro de Informação em Ciência e Tecnologia, 2016. $\quad$ Disponível em: $<$ http: //livroaberto.ibict.br/bitstream/123456789/1063/4/Manual-Archivematica.pdf >. Acesso em: 12 nov. 2016. p. 13.

${ }^{38}$ FLORES, Daniel. Sistemas informatizados de acesso e gestão da preservação em documentos históricos permanentes. Fórum Permanente: as instituições-memória e as tecnologias da informação e comunicação: desafios contemporâneos. Campinas - SP. 61 slides, color, Padrão Slides Google Drive/Docs 4x3. Material elaborado para a Palestra na Unicamp, 12 abr. 2016. Disponível em: <http://documentosarquivisticosdigitais.blogspot.com.br/2016/08/sistemas-informatizados-de-acessoe.html>. Acesso em: 12 abr. 2016.

${ }^{39}$ COSTA, Milene et al. Guia do usuário Archivematica. Brasília: Instituto Brasileiro de Informação em Ciência e $2016 . \quad$ Tecnologia, Disponível em: <http://livroaberto.ibict.br/bitstream/123456789/1063/4/Manual-Archivematica.pdf >. Acesso em: 12 nov. 2016. p. 16.

${ }^{40}$ COSTA, Milene et al. Guia do usuário Archivematica. Brasília: Instituto Brasileiro de Informação em Ciência e Tecnologia, 2016. Disponível em: <http://livroaberto.ibict.br/bitstream/123456789/1063/4/Manual-Archivematica.pdf >. Acesso em: 12 nov. 2016. p. 22. 
Repositório Arquivístico Digital Confiável (Archivematica) e, em terceiro, a Plataforma de Descrição, Difusão e Acesso (AtoM ou ICA-AtoM). Por fim, a reunião das três plataformas cria o chamado Ambiente de Preservação e Acesso ${ }^{41}$.

O uso de um sistema como esse é deveras importante para a preservação documental, inclusive no campo do Direito. Conforme se verifica no Guia do Usuário do Archivematica, na idade permanente, os documentos precisam ser recolhidos para um RDC-Arq, a fim de serem preservados com garantia de acesso. No ponto, diferenciando-se do que ocorre nas outras idades (corrente e intermediária), o RDC-Arq não permite a eliminação de documentos na idade permanente. Desse modo, o recolhimento não é algo opcional mas sim obrigatório e necessário em prol da necessidade de preservação dos documentos a longo prazo, premissa maior desta análise ${ }^{42}$.

Outrossim, o software foi escolhido pelo Arquivo Nacional para o Projeto da CNVComissão Nacional da Verdade, o que denota a ampliação das atenções para sua utilização ${ }^{43}$. Dentre os pontos favoráveis oferecidos pelo software Archivematica, está o de dar aos Arquivistas e aos Bibliotecários a confiança necessária a fim de que sejam realizadas as preservações digitais de hoje de forma segura e prática. No ponto, ele foi minuciosamente analisado pelas experiências de implantação e de feedbacks de usuários, pois é um integrado de tecnologia, pessoas, processos ${ }^{44}$.

De toda sorte, verifica-se que o uso do Archivematica está ganhando força por ser um software livre e que permite que sejam feitas alterações e adaptações necessárias para sua

${ }^{41}$ COSTA, Milene et al. Guia do usuário Archivematica. Brasília: Instituto Brasileiro de Informação em Ciência e $\quad$ Tecnologia, 2016. <http://livroaberto.ibict.br/bitstream/123456789/1063/4/Manual-Archivematica.pdf>. Acesso em: 12 nov. 2016. p. 11.

${ }^{42}$ COSTA, Milene et al. Guia do usuário Archivematica. Brasília: Instituto Brasileiro de Informação em Ciência e $\quad 2016 . \quad$ Tecnologia, Disponível em: <http://livroaberto.ibict.br/bitstream/123456789/1063/4/Manual-Archivematica.pdf>. Acesso em: 12 nov. 2016. p. 13.

${ }^{43}$ COSTA, Milene Aparecida Silva da; CASTRO, Priscila de Paiva. Archivematica uma Ferramenta de Software livre para preservação de documentos arquivísticos digitais. Revista Intercâmbio dos Congressos Internacionais de Humanidades, Brasília, n. 6, p. 106-119, 2016. Disponível em: <http://unb.revistaintercambio.net.br/24h/pessoa/temp/?file=anexo, 1,11625,3008,3008.Archivematica\%2 0uma\%20Ferramenta\%20de\%20Software\%20livre\%20para\%20preserva\%C3\%A7\%C3\%A30\%20de\%20documentos \%20arquiv\%C3\%ADsticos\%20digitais>. Acesso em: 15 ago. 2016.

44 COSTA, Milene Aparecida Silva da; CASTRO, Priscila de Paiva. Archivematica uma Ferramenta de Software livre para preservação de documentos arquivísticos digitais. Revista Intercâmbio dos Congressos Internacionais de Humanidades, Brasília, n. 6, p. 106-119, 2016. Disponível em: <http: / / unb.revistaintercambio.net.br/24h/pessoa/temp/?file=anexo,1,11625,3008,3008. Archivematica\%2 0uma\%20Ferramenta\%20de\%20Software\%20livre\%20para\%20preserva\%C3\%A7\%C3\%A30\%20de\%20documentos \%20arquiv\%C3\%ADsticos\%20digitais>. Acesso em: 15 ago. 2016. 
ISSN 1981-3694

(DOI): 10.5902/1981369425362

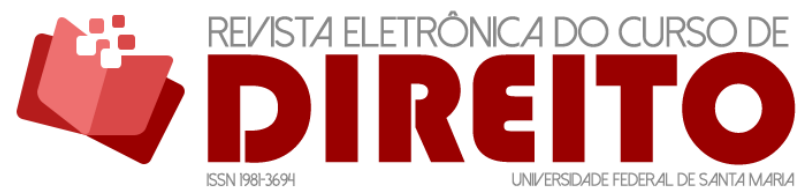

DO PROCESSO ELETRÔNICO AO DOCUMENTO PÚBLICO: UMA ANÁLISE DA CONSERVAÇÃO DOS AUTOS COMO ARQUIVOS

PERMANENTES

ELAINE HARZHEIM MACEDO RENAN MATHEUS MACEDO TOLFO

plena adequação ao ambiente em que se encontra. Outrossim, o Archivematica faz parte da cadeia necessária, isto é, de um sistema ideal, baseado nas melhores práticas arquivísticas para a guarda documental.

A fim de que se possa efetivamente preservar os documentos produzidos no Poder Judiciário de modo eficiente, faz-se necessário a multidisciplinariedade entre Direito, História e Arquivologia. A previsão constitucional e legal do dever de preservar só será cumprida através de uma análise multidisciplinar, de modo que cada área possa contribuir em tal desiderato. No ponto, curva-se diante de uma necessidade premente. A utilização do Archivematica é uma grande contribuição oferecida pela Arquivologia na gestão de documentos, especialmente na de cunho permanente. Assim, tem-se que a implantação deste sistema é uma possível realidade para preservar os arquivos digitais de acordo com as melhores práticas da arquivística, de modo que se constitui num sistema ideal de preservação de arquivos digitais voltado a cumprir o dever maior de guarda e acesso aos documentos públicos.

\section{CONCLUSÃO}

A importância dos arquivos judiciais como depositários da história pública e privada do povo brasileiro, o que é reconhecido na Constituição republicana, só passou a receber atenção maior a partir da década de noventa, especialmente com o advento da Lei $n^{\circ}$ 8.159/1991, embora ainda tenha levado cerca de uma década para que as primeiras providências fossem tomadas, incialmente no âmbito da administração dos tribunais, posteriormente através de resoluções do Conselho Nacional da Justiça, quando da edição da Resolução $n^{\circ}$ 70, de 18 de março de 2009. Não foi diferente no âmbito dos demais poderes, na medida em que a Lei de Arquivos Públicos só veio a ser regulamentada pelo Decreto $\mathrm{n}^{\circ} 4.073$, em 2002, ou seja, onze anos após a edição do referido estatuto.

Por outro lado, no percurso desses mais de vinte anos da edição da Lei de Arquivos Públicos, no escopo de se construir uma teoria e prática de guarda documental, de início voltadas exclusivamente para a documentação em papel, a ciência e a tecnologia da informação foram vencendo etapas e se aperfeiçoando na utilização de mídias eletrônicas, tanto no âmbito das relações privadas como nas relações públicas.

No processo, como espaço de produção da jurisdição, não foi diferente, avançando-se, ainda que de forma titubeante, do processo em meio físico para o processo em meio digital, em especial aqui destacando a Lei $\mathrm{n}^{\circ} 11.419 / 2016$, mostrando-se indispensável que os arquivos 
ISSN 1981-3694

(DOI): $10.5902 / 1981369425362$

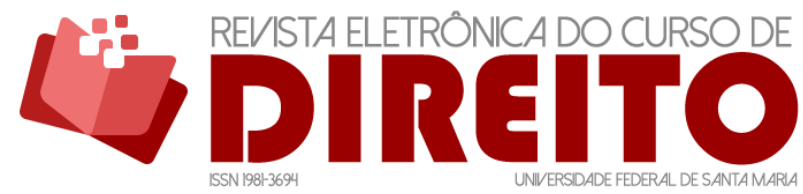

DO PROCESSO ELETRÔNICO AO DOCUMENTO PÚBLICO: UMA ANÁLISE DA CONSERVAÇÃO DOS AUTOS COMO ARQUIVOS

PERMANENTES

ELAINE HARZHEIM MACEDO RENAN MATHEUS MACEDO TOLFO

judiciais precisam ser enfrentados à luz da interdisciplinaridade, na medida em que é o Direito e a História que estabelecem os critérios dos documentos a serem guardados, preocupação esta que deve, na medida do possível, ser estabelecida originalmente, quando o processo se instaura, ainda como documento corrente, com vistas ao seu futuro, quando de documento corrente se transformará em documento intermediário. Os documentos intermediários, segundo a tabela de temporalidade própria, serão guardados por um determinado período, até sua eliminação, ou, quando catalogados como documentos permanentes, dado seu relevante valor histórico, receberão guarda permanente. Tais conceitos aplicam-se indistintamente no documento produzido em papel e no documento digital. No caso do arquivo digital, há um risco ainda mais evidente de que, se não forem cumpridas as etapas de preservação da maneira necessária, tal arquivo possa ter comprometido seus valores, dentre eles o probatório e histórico.

Daí porque indispensável a Ciência e a Tecnologia da Informação contribuírem para o desenvolvimento da adequada preservação no tempo da memória digital, daquilo a que se propõe o sistema denominado Archivematica, cumprindo aos órgãos públicos se modernizarem e se adaptarem, na sua auto-organização, às exigências decorrentes desta nova era, em que a informação está de mãos dadas com os documentos públicos.

Portanto, como resultado verificou-se que o Archivematica atende aos requisitos de preservação a longo prazo e autenticidade, além de ser um software livre que permite fazer o armazenamento de documentos em vários formatos. É importante sinalizar que o uso do Archivematica para a preservação digital constitui-se numa contribuição valiosíssima para o Poder Judiciário, na medida em que propicia ferramentas para a preservação documental e integração com meios que permitem o acesso a tais documentos digitais, inclusive os de cunho permanente.

\section{REFERÊNCIAS}

ABRÃO, Carlos Henrique. Processo eletrônico: Lei n 11.419 de 19 de dezembro de 2006. 2. ed. São Paulo: Revista dos Tribunais, 2009.

BRASIL. Arquivo Nacional. Resolução CONARQ n 26 de 06 de maio de 2008. Estabelece diretrizes básicas de gestão de documentos a serem adotadas nos arquivos do Poder Judiciário. Disponível em: <http://www.conarq.arquivonacional.gov.br/legislacao/resolucoesdoconarq/268resolucaon-26,-de-06-de-maio-de-2008.html>. Acesso em: 15 ago. 2016.

BRASIL. Conselho Nacional de Justiça. Manual de Gestão Documental. Disponível em: <http://www.cnj.jus.br/images/programas/gestaodocumental/manual_gestao_documental_pod er\%20judiciario.pdf>. Acesso em: 15 ago. 2016. 
BRASIL. Conselho Nacional de Justiça. Modelo de Requisitos para Sistemas Informatizados de Gestão de Processos e Documentos do Judiciário brasileiro - MoReq-Jus. Disponível em: <http://www.cnj.jus.br/images/programas/gestaodocumental/rescnj_91.pdf>. Acesso em: 15 ago. 2016.

BRASIL. Conselho Nacional de Justiça. Recomendação n 37, de 15 de agosto de 2011. Recomenda aos Tribunais a observância das normas de funcionamento do Programa Nacional de Gestão Documental e Memória do Poder Judiciário - Proname e de seus instrumentos. Disponível em: <http://www.cnj.jus.br/images/stories/docs_cnj/recomendacoes/reccnj_37.pdf>. Acesso em: 15 ago. 2016.

BRASIL. Constituição Federal. Diário Oficial da União, Brasília, DF, 5 out. 1988. Disponível em: <http://www.planalto.gov.br/ccivil_03/constituicao/constituicao.htm>. Acesso em: 15 ago. 2016.

BRASIL. Decreto $n^{\circ} 4.073$, de 3 de janeiro de 2002. Regulamenta a Lei $n^{\circ} 8.159$, de 8 de janeiro de 1991, que dispõe sobre a política nacional de arquivos públicos e privados. Diário Oficial da República Federativa do Brasil, Brasília, 4 jan. 2002. Disponível em: <http://www.planalto.gov.br/ccivil_03/decreto/2002/d4073.htm>. Acesso em: 15 ago. 2016.

BRASIL. Decreto ${ }^{\circ} 8.539$, de 8 de outubro de 2015. Dispõe sobre o uso do meio eletrônico para a realização do processo administrativo no âmbito dos órgãos e das entidades da administração pública federal direta, autárquica e fundacional. Diário Oficial da República Federativa do Brasil, Brasília, 9 out. 2015. Disponível em: <http://www.planalto.gov.br/ccivil_03/_Ato20152018/2015/Decreto/D8539.htm>. Acesso em: 12 nov. 2016.

BRASIL. Lei n 8.159 , de janeiro de 1991. Dispõe sobre a política nacional de arquivos públicos e privados e dá outras providências. Diário Oficial da República Federativa do Brasil, Brasília, 9 jan. 1991. Disponível em: <http://www.planalto.gov.br/ccivil_03/LEIS/L8159.htm>. Acesso em: 15 ago. 2016.

BRASIL. Superior Tribunal Militar. IV Congresso Brasileiro de Arquivos do Poder Judiciário, Brasília, 18, 19 e 20 nov. 2015. Disponível em: <https://www.stm.jus.br/IV-congresso-brasileirode-arquivos/>. Acesso em: 12 nov. 2016.

CHAVES JÚNIOR, José Eduardo de Resende. 0 processo em rede. In: CHAVES JÚNIOR, José Eduardo de Resende (Coord.). Comentários à lei do processo eletrônico. São Paulo: LTr, 2010.

COSTA, Milene Aparecida Silva da; CASTRO, Priscila de Paiva. Archivematica uma Ferramenta de Software livre para preservação de documentos arquivísticos digitais. Revista Intercâmbio dos Congressos Internacionais de Humanidades, Brasília, n. 6, p. 106-119, 2016. Disponível em: <http: / / unb.revistaintercambio.net.br/24h/pessoa/temp/?file=anexo, 1, 11625, 3008, 3008. Archiv ematica\%20uma\%20Ferramenta\%20de\%20Software\%20livre\%20para\%20preserva\%C3\%A7\%C3\%A30\%2 0de\%20documentos\%20arquiv\%C3\%ADsticos\%20digitais>. Acesso em: 15 ago. 2016.

COSTA, Milene et al. Guia do usuário Archivematica. Brasília: Instituto Brasileiro de Informação em Ciência e Tecnologia, 2016. Disponível em:

<http: / / livroaberto.ibict.br/bitstream/123456789/1063/4/Manual-Archivematica.pdf>. Acesso em: 12 nov. 2016. 
COOK, Terry. Archival Science and Postmodernism: new formulations for old concepts. Archival Science, v. 1, p. 13-24, 2000. Disponível em: <http://www.mybestdocs.com/cook-t-postmodp1-00.htm>. Acesso em: 12 nov. 2016.

DOCUMENTO histórico: Peças do processo crime mãos amarradas: denúncia e habeas corpus. Direito e democracia, Universidade Luterana do Brasil, v. 6, n. 2, $2^{\circ}$ sem. 2005. Canoas: Ulbra, 2005, p. 513-522.

FLORES, Daniel. Sistemas informatizados de acesso e gestão da preservação em documentos históricos permanentes. Fórum Permanente: as instituições-memória e as tecnologias da informação e comunicação: desafios contemporâneos. Campinas - SP. 61 slides, color, Padrão Slides Google Drive/Docs 4x3. Material elaborado para a Palestra na Unicamp, 12 abr. 2016. Disponível em: <http: / / documentosarquivisticosdigitais.blogspot.com.br/2016/08/sistemasinformatizados-de-acesso-e.html>. Acesso em: 12 abr. 2016.

MEDEIROS, Nilcéia Large de; AMARAL, Cléia Márcia Gomes do. A representação do ciclo vital dos documentos: uma discussão sob a ótica da gestão de documentos. Em Questão, Porto Alegre, v. 16, n. 2, p. 297-310, jul./dez. 2010. Disponível em:

<http://www.seer.ufrgs.br/EmQuestao/article/view/15108/10436>. Acesso em: 14 nov. 2016.

NEGREIROS, Leandro Ribeiro; DIAS, Eduardo José Wense. A prática arquivística: os métodos da disciplina e os documentos tradicionais e contemporâneos. Perspectivas em Ciência da Informação, v. 13, n. 3, p. 2-19, set./dez. 2008. Disponível em: <http://www.scielo.br/pdf/pci/v13n3/a02v13n3.pdf>. Acesso em: 15 ago. 2016.

RIO GRANDE DO SUL. Justiça Federal. Acervo Histórico. Disponível em: <https://www2.jfrs.jus.br/acervo-historico/>. Acesso em: 14 nov. 2016.

TEIXEIRA, Tarcísio. Curso de direito e processo eletrônico: doutrina, jurisprudência e prática. São Paulo: Saraiva, 2013.

UNESCO. A memória do mundo na era digital: digitalização e preservação. Disponível em: <http://www.unesco.org/new/fileadmin/MULTIMEDIA/HQ/Cl/Cl/images/mow/u nesco_ubc_vancouver_declaration_pt.pdf >. Acesso em: 14 nov. 2016.

UNESCO. Memória do mundo: diretrizes para a salvaguarda do patrimônio documental mundial. Disponível em: <http://mow.arquivonacional.gov.br/images/pdf/Edital_MoWBrasil_2017.pdf>. Acesso em: 12 nov. 2016.

\section{COMO FAZER A REFERÊNCIA DO ARTIGO (ABNT):}

MACEDO, Elaine Harzheim; TOLFO, Renan Matheus Macedo. Do processo eletrônico ao documento público: uma análise da conservação dos autos como arquivos permamentes. Revista Eletrônica do Curso de Direito da UFSM, Santa Maria, RS, v. 12, n. 3, p. 709-734, dez. 2017. ISSN 1981-3694. Disponível em: <https://periodicos.ufsm.br/revistadireito/article/view/25362>. Acesso em: dia mês. ano. doi:http://dx.doi.org/10.5902/1981369425362. 